\title{
Organization and Financial Support of Innovative Processes in Russia
}

\author{
Tatiana Pogodina \\ Management Department \\ Financial University under the Government of the Russian Federation \\ Moscow, Russia \\ pogodina15@yandex.ru
}

\begin{abstract}
The article considers theoretical and practical aspects of the "open innovations" concept implementation, which is a paradigm of innovations in general. It substantiates the concept's most successful implementation in territorial clusters due to the formation of the agglomeration effect therein. The studies included advanced Russian regions engaged in the formation of innovative territorial clusters (Samara and Kaluga regions, the Republic of Tatarstan). The financial support of innovative processes in Russia during 2000-2015 has been reviewed. Proposals on the improvement of the innovation processes management system in the regions of Russia were formulated.
\end{abstract}

Keywords-open innovation; territorial cluster; innovative processes financing

\section{INTRODUCTION}

Innovative processes of economic entities are the most important factors of economic growth and modernization of the country. They are characterized by a high level of uncertainty and risk, a complex structure, the difficulty of predicting the end result. Nevertheless, it is the innovative processes that drive the development of individual market players, as they promote the creation of a competitive advantage for separate companies, allow them to make a significant shoot forward, get a new unique product or service. Innovative development is laid as the main priority in the economic policy of our country.

The purpose of this study is to substantiate the main directions of innovative processes development based on the cluster approach. The study of competitive factors in the implementation of innovative processes was based on the modern methodology of cluster analysis, methods of systematization, statistical and factor analysis.

\section{THEORETICAL FUNDAMENTALS AND FEATURES OF INNOVATIVE PROCESS DEVELOPMENT}

Over the last years, the strategy for the development of companies and regions, which is based on the concept of "Open innovations" has become popular in economics. The founder of the theory of open innovations is G. Chesbro, a professor at the University of California. Since 2003, he has published two of his works on the problem of open innovations, which stated the essence of his theory and the practical aspects of implementing his concept.

According to G. Chesbro, the "open innovation is the use of purposeful incoming and outgoing flows of knowledge to accelerate innovation. With a wide dissemination of knowledge, companies cannot entirely rely on their own research, but must acquire inventions and intellectual property from other companies, when this allows improving the business model" [1]. At present, the concept of open innovations has become so popular all over the world that it can become a paradigm of innovation in general. Open innovations can be successfully implemented in territorial clusters, which represent a group of geographically localized companies of linked industries that ensure their competitiveness in world markets due to the agglomeration effect.

The concept of "open innovations" is a priority-oriented for Russia. When considering the features of innovation processes in Russia, it should be noted that in recent years, companies have become increasingly focused on developing their innovative activity. However, many unresolved problems remain in the economic development at large and in innovative activity of companies in particular, including the lack of major domestic innovative companies that are able to share the experience of practical innovation activity with the others; the difficulty in attracting financial resources at the stage of introduction of innovative developments due to the high cost of the innovation commercialization and the duration of the payback period; the lack of the necessary regulatory and legal acts that could govern the innovation activities in companies. In addition, many Russian companies do not have a modern technological base for research. As a result, in 2014 only $8.8 \%$ of manufacturing companies carried out technological innovations (compared to $55.0 \%$ in Germany, $45.2 \%$ in Sweden, $36.7 \%$ in France, and $34.0 \%$ in the United Kingdom). Consequently, our country lags behind the most developed countries in Europe by several times in terms of the pace of development of innovation processes [2]. Therefore, the issues of stimulating innovation processes should be coordinated at the level of federal and regional governments. 


\section{THE CONTROL MECHANISM OF TERRITORIAL CLUSTERS}

The formation of territorial clusters, especially innovative ones can be a conductor of stimulating the innovative processes development. The great attention is given to formation of territorial clusters in the regions of the Central (Central Federal District) and Volga (VFD) federal districts. In the VFD, the leaders in the formation of territorial clusters are Samara Region and the Republic of Tatarstan. In Samara region, the leading role is played by the aerospace cluster, which consists of two sub-clusters: rocket and space and aircraft. This cluster has a high level of competitiveness in world markets. An innovative and implemental cluster is formed in the region, the successful functioning of which is determined by the significant innovative potential of the region.

Kaluga region is one of the Russian leaders in resolving the issue of innovative territorial clusters development. At present, Kaluga region is in the second stage of development (2014 - 2019), at which one of the main development priorities is the formation of spatial clusters directly related to innovative developments. In Kaluga region, the following clusters have been created and dynamically developing: biopharmaceutical, a cluster of automobile construction, a transport and logistics cluster, an ICT cluster, an aerospace cluster (cluster of composite materials). The pharmaceutical cluster of Kaluga region is developing on an innovative basis. For example, the "Active Molecule Park" of Obninsk group of companies "Medbiopharm" supports the commercialization of biochemical scientists. The company cooperates with the Skolkovo Foundation [3]. Inside the clusters of the Kaluga region, there are modern structures specific for the "knowledge economy", such as techno parks, business incubators, and centers of collective use, innovation and technology centers.

The active development of innovative processes in Kaluga region has become largely possible due to its interaction with federal development institutions, such as the State Corporation ROSNANO, Russian Venture Company, OJSC, the Seed Investment Fund of RVC, OJSC, the Foundation for Assistance to Development of Small Innovative Enterprises, Innovation Center Skolkovo. In 2011 an agreement was signed between the Agency for Innovative Development - Cluster Development Center of Kaluga region, OJSC and the Montpellier agglomeration (France) on cooperation in promotion of Russian pilot projects to European markets. It is advisable to distribute such positive experience throughout Russia.

In general, the management of innovation processes in many regions of Russia is carried out through the Cluster Development Centers, which carry out the tasks of direct cluster management in the project's design for its development and investment programs, and the development and implementation of joint cluster projects involving all stakeholders [4].

The integrated cluster development program should include goals, objectives, priorities, optimization of the financial structure of its activities, etc.

\section{FinANCIAL SUPPORT OF INNOVATIVE PROCESSES IN TERRITORIAL CLUSTERS}

The necessary condition for the implementation of innovative processes in the company is the availability of financial resources. Structurally, the sources of financing for companies' innovative processes can be divided into main groups - equity funds and external sources of financing. When considering the Russian practice of financing companies' innovative processes, it is advisable to analyze statistical data on the financial structure of domestic expenditures on research and development (Table) [2].

Analyzing the data shown in "Table I", you can see that the largest share in the internal costs of research and development is taken by the budget (more than 60\% in 20102015). At the same time, there is a tendency for a gradual increase in the share of the budget in financing innovative development (53.7\% in 2000 against $67.5 \%$ in 2015). State financing of companies' innovative processes can be carried out in various forms, such as providing grants, guarantees, credits, loans, subsidies, contributions to the authorized capital.

At the same time, the share of funds of the business sector organizations tends to decrease from $18.7 \%$ in 2000 to $16.5 \%$ in 2015 . As the equity funds of companies attributable to the innovative processes financing, it is necessary to allocate the following: retained earnings, special purpose funds, additional capital, and reserve capital.

TABLE I. STRUCTURE OF DOMESTIC EXPENDITURES ON RESEARCH AND DEVELOPMENT BY SOURCES OF FINANCING IN RUSSIA FOR 2000$2015 \%$.

\begin{tabular}{|c|c|c|c|c|}
\hline Sources of Financing & 2000 & 2010 & 2013 & 2015 \\
\hline $\begin{array}{l}\text { Equity funds of scientific } \\
\text { organizations }\end{array}$ & 9.1 & 9.1 & 12.1 & 12.0 \\
\hline Budgetary funds & 53.7 & 68.8 & 65.8 & 67.5 \\
\hline $\begin{array}{l}\text { Funds of extra-budgetary } \\
\text { foundations }\end{array}$ & 6.5 & 1.9 & 1.6 & 1.0 \\
\hline $\begin{array}{lcc}\begin{array}{l}\text { Funds of } \\
\text { organizations }\end{array} & \text { business sector } \\
\end{array}$ & 18.7 & 16.4 & 17.2 & 16.5 \\
\hline $\begin{array}{l}\text { Funds of educational organizations } \\
\text { of higher education }\end{array}$ & 0.1 & 0.1 & 0.2 & 0.3 \\
\hline $\begin{array}{l}\text { Funds of private non-profit } \\
\text { organizations }\end{array}$ & 0.1 & 0.1 & 0.1 & 0.1 \\
\hline Funds of foreign sources & 12.0 & 3.5 & 3.0 & 2.7 \\
\hline
\end{tabular}

In addition, the participation of foreign capital in research and development financing in Russia has significantly decreased and amounted to only $2.7 \%$ in 2015 compared to $12.0 \%$ in 2000 . This is an alarming trend, indicating a decrease in the investment attractiveness of the Russian economy.

In general, it is necessary to develop a mechanism for financial support of innovative processes, which sets the trajectory of the transition from a rent-oriented to innovativeoriented type of Russian economy. 


\section{DiRECTIONS OF INNOVATIVE PROCESSES DEVELOPMENT IN TERRITORIAL CLUSTERS}

The specific activities to ensure the sustainable innovation development should include:

- Conducting regional competitions for the most progressive organizational and economic management of innovative projects in clusters;

- Formation of the catalog of the most innovativeactive clusters, companies of the region;

- Certification, introduction of modern methods and systems of public finance management to stimulate the innovative development of the region;

- Reorientation of the state's structural policy to support innovative territorial clusters;

- Carrying out of inspection, monitoring and audit of cluster projects and cluster programs;

- Creation of own scientific base in the cluster;

- Formation of clear mechanisms for tax incentives for innovation activities;

- Application of the indicative planning system on the indicators of innovation development to micro(enterprise), meso - (clusters, industries and complexes) and macro levels;

- Improving the quality and validity of forecasts, personnel strengthening of the forecast and planning service in the regional authorities;

- Development of the Corporate Management Code (with emphasis on innovation);

- Development of methods, tools and technologies for strategic planning and management at the regional and cluster levels;

- Formation of a risk management system in territorial clusters, etc.

In the current conditions of the development of a market economy, there is a tendency to support clusters of interregional and world level, enhance inter-cluster interaction and cluster management.

\section{CONCLUSION}

Thus, in modern development conditions of the Russian regions, innovative processes are activated, which are concentrated in territorial clusters. The key task in the midterm is to improve the level of innovation processes management, including the improvement of the organizational structure, personnel and financial support for activities in territorial clusters that ensure the competitiveness of regional and national economies.

\section{REFERENCES}

[1] G. Chesbro, Open innovation: the creation of profitable technology / G. Chesbro. - Moscow: Generation, 2007.

[2] Federal Service of State Statistics (official website). [E-source] Access mode: http://www.gks.ru.

[3] Association of Innovative Regions of Russia [E-source]. - Access mode: http://www.i-regions.org.

[4] Financial and economic mechanisms for creating innovative territorial clusters: monograph / T. V. Pogodina, N. V. Kuznetsov, N. M. Abdikeev, E. B. Tyutyukina, L. D. Kapranova, Moscow: RUSAINS, 2016 